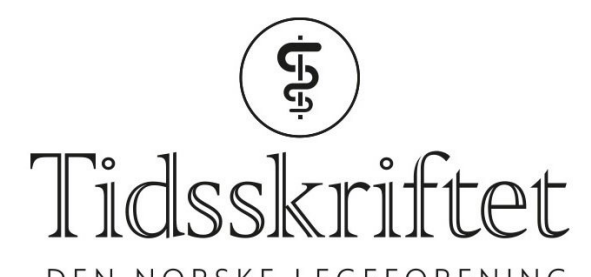

DEN NORSKE LEGEFORENING

\title{
Suppe til besvær
}

MEDISINEN I BILDER

\section{GEIR WENBERG JACOBSEN}

Geir Wenberg Jacobsen (f. 1945) er professor emeritus ved Norges teknisk-naturvitenskapelige universitet og medisinsk redaktør i Tidsskriftet.

Forfatter har fylt ut ICMJE-skjemaet og oppgir ingen interessekonflikter.

\section{ELENA TITOVA}

Elena Titova (f. 1981) er spesialist og overlege i lungesykdommer ved St. Olavs hospital. Forfatter har fylt ut ICMJE-skjemaet og oppgir ingen interessekonflikter.

\section{JAN PÅL LOENNECHEN}

Jan Pål Loennechen (f. 196o) er dr. med., overlege i hjertesykdommer ved St. Olavs hospital og førsteamanuensis i kardiologi ved Norges teknisk-naturvitenskapelige universitet. Forfatter har fylt ut ICMJE-skjemaet og oppgir ingen interessekonflikter.

\section{ERIK MAGNUS BERNTSEN}

Erik Magnus Berntsen (f. 1982) er ph.d., overlege i radiologi ved St. Olavs hospital og førsteamanuensis i radiologi ved Norges teknisk-naturvitenskapelige universitet.

Forfatter har fylt ut ICMJE-skjemaet og oppgir ingen interessekonflikter.

En mann, tidlig i 7o-årene, oppsøkte legevakten med frostanfall og nedsatt allmenntilstand. Temperaturen ble målt til $40,6{ }^{\circ} \mathrm{C}$, og blodprøvene viste CRP på $115 \mathrm{mg} / \mathrm{l}(<5)$ og leukocytter på $12,9 \cdot 10^{8}\left(4,1^{-9}, 8 \cdot{ }^{\prime} 10^{8}\right)$. To døgn før fikk han utført en elektrokonvertering grunnet et atrieflimmeranfall som hadde debutert fem dager før den aktuelle hendelsen. Denne tilstanden var kjent, men pasienten hadde vært uten symptomer etter en radiofrekvensablasjon for to år siden.

På grunn av klinisk mistanke om pneumoni ble det tatt røntgen thorax (se røntgenbildet) som viste en fortetning i høyre underlapp. Etter hvert kom det frem at pasienten flere uker tidligere hadde spist kjøttsuppe med grønnsaker, og at han under måltidet hadde registrert at «noe» forsvant ned i luftrøret. 


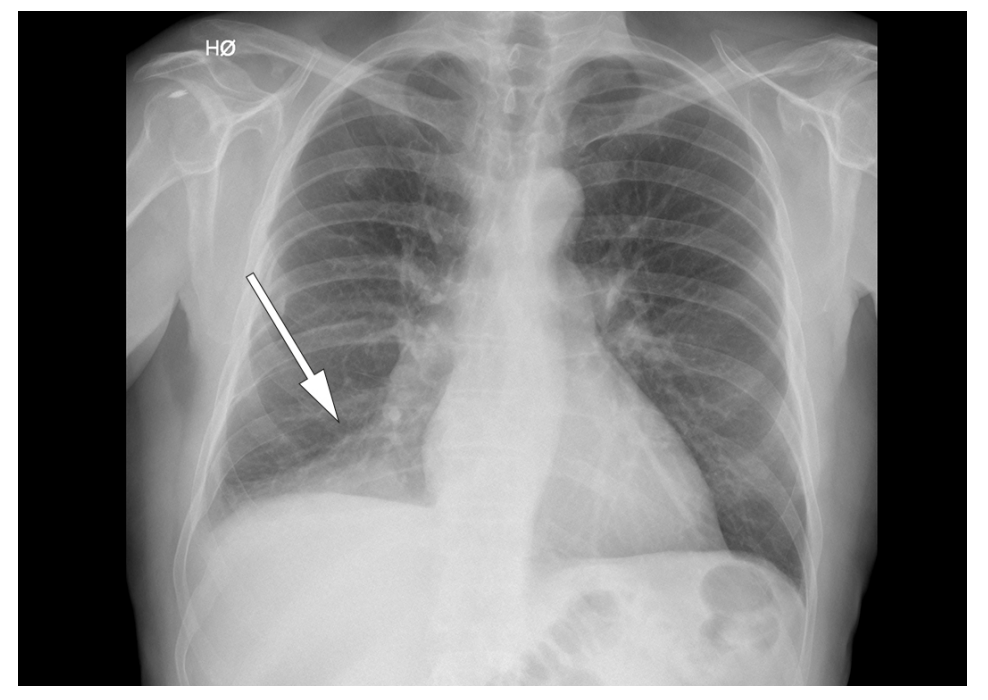

Sykehistorien reiste nå spørsmål om fremmedlegeme, og pasienten ble innlagt i lungeavdelingen for behandling med penicillin intravenøst og videre utredning. Før bronkoskopi ble det utført CT thorax (se CT-bildet) som viste en $8 \mathrm{~mm}$ rund forandring proksimalt i høyre underlappsbronkus. Denne ga nær full okklusjon av lumen og forårsaket atelektase av høyre underlapp distalt.

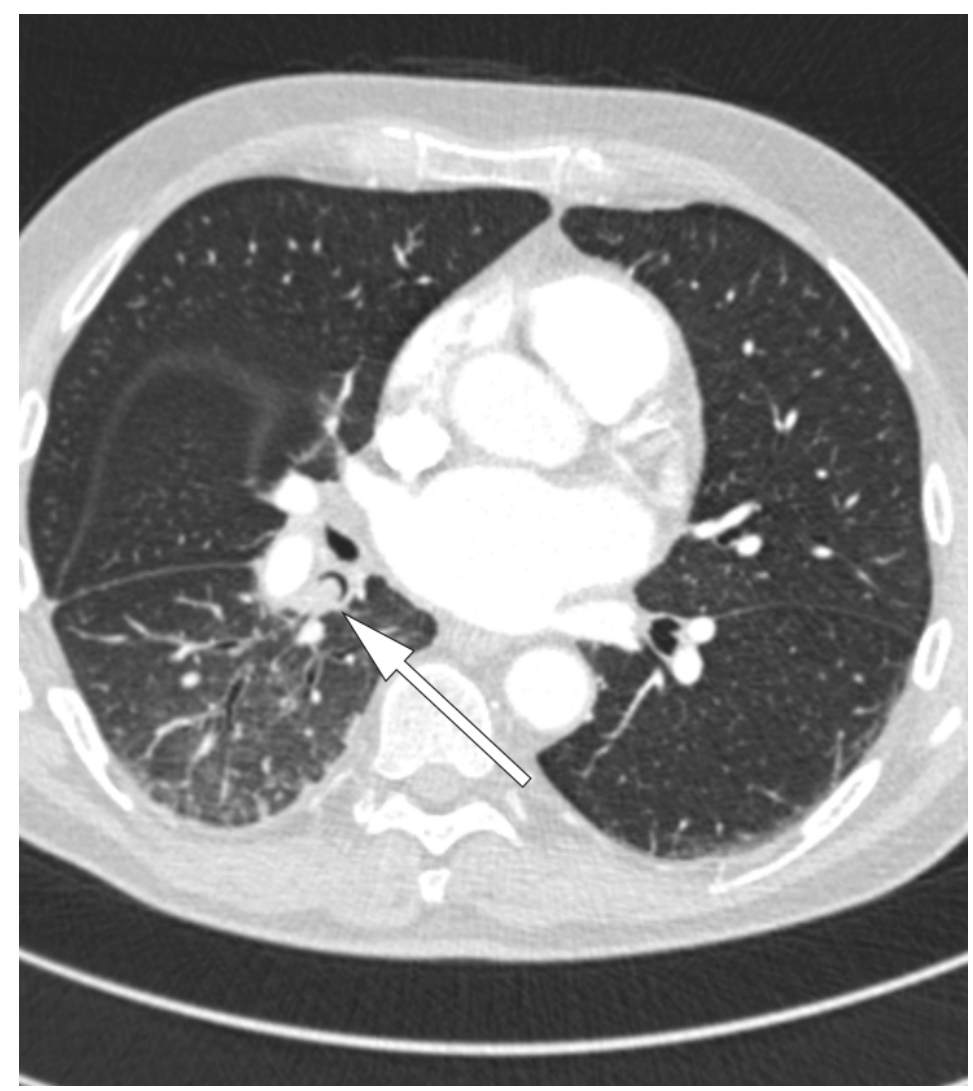

Bronkoskopi ble utført (se endoskopibildet), og en ert ble lokalisert som beskrevet på CTundersøkelsen og deretter fjernet (se video). Erten var uskadd med en diameter på ca. $10 \mathrm{~mm}$. Pasienten ble feber- og symptomfri i løpet av en kort uke, og røntgen thorax etter åtte uker viste full tilbakegang av atelektasen. Etterkontroll med bronkoskopi var også normal.

Aspirasjon av linser eller erter med påfølgende pneumoni er ingen ny problemstilling. Tilstanden ble rapportert med ujevne mellomrom på slutten av 19oo-tallet (1), gjerne som enkeltstående kasuistikker. Tross beskjedne symptomer og langsom utvikling endte sykdommen ofte fatalt, og ble først bekreftet ved obduksjon. Det hang sammen med at de mest utsatte var små barn, psykisk debile voksne, i tillegg til eldre og sengeliggende pleiepasienter. 
LITTERATUR:

1. Ros PR. Lentil aspiration pneumonia. JAMA 1984; 251: 1277 - 8. [PubMed][CrossRef]

Publisert: 12. juni 2018. Tidsskr Nor Legeforen. DOI: 10.4045/tidsskr.17.1025

Mottatt 20.11.2017, første revisjon innsendt 22.3.2018, godkjent 24.4.2018. Setteredaktør: Michael Bretthauer

(C) Tidsskrift for Den norske legeforening 2020. Lastet ned fra tidsskriftet.no 